\title{
IL NAZIONALISMO DELLA LETTERATURA BRITANNICA PRIMA DELLA GRANDE GUERRA E L'ESPERIENZA DEI WAR POETS
}

\author{
Angelo Giunta \\ angelogiunta@libero.it
}

\section{Riassunto}

L'immagine di un Regno Unito visto come Eden inconsapevole della tragedia che sta per lacerarlo è diffusa, ma piuttosto falsa. L'apparente serenità nasconde una violenza latente e gravi questioni interne e la guerra, quindi, non fa altro che accelerare un processo già in atto.

Di tutta la letteratura inglese del Ventesimo secolo, la poesia di guerra sembra, sotto molti punti di vista, una "parentesi" all'interno del panorama letterario. La war poetry è il prodotto di un determinato periodo storico, sociale e culturale venutosi a formare nella Prima guerra mondiale. Tra i migliori poeti della Grande Guerra troviamo Rupert Brooke, Wilfred Owen e Siegfried Sassoon. Il fatto che molti poeti siano ufficiali - ma non alti ufficiali - permette loro di essere in contatto, a livello socio-culturale, con i ranghi elevati dell'esercito e, fisicamente, con i soldati semplici. In questo modo hanno una visione più ampia della realtà in trincea.

Parole chiave: war poets, Grande Guerra, Rupert Brooke, Wilfred Owen, Siegfrid Sassoon 


\section{Il Regno Unito negli anni che precedono la Grande Guerra}

L'immagine di un Regno Unito visto come Eden inconsapevole della tragedia che sta per lacerarlo è diffusa, ma piuttosto falsa. L'apparente serenità nasconde una violenza latente e gravi problemi interni e la guerra, quindi, non fa altro che accelerare un processo già in atto. La stabilità del paese è minacciata da tensioni politiche, economiche e sociali, fra cui la rivolta dei Tory nell'Ulster. Nel 1911 il governo presenta un progetto chiamato Home Rule che prevede un'Irlanda autonoma e con un proprio parlamento. La soluzione scontenta la minoranza protestante dell'Irlanda del Nord, che organizza un movimento armato di opposizione. Dopo un lungo dibattito il progetto viene approvato nel maggio 1914, ma la sua applicazione è sospesa a causa dello scoppio della guerra, avvenuto nell'agosto dello stesso anno (Trevelyan, 1977, 809). Probabilmente se il paese non entrasse in guerra nell'agosto del 1914, dovrebbe affrontare una guerra civile in Irlanda e uno sciopero generale di proporzioni mai viste. (Bergonzi, 1965, 21).

Alcuni scrittori sembrano consapevoli di tali pericoli e, da diversi decenni, una preoccupazione comune è proprio il timore di un'imminente guerra e di una possibile invasione del paese. L'esempio più rilevante dal punto di vista letterario è The War of the Worlds (1898) di Herbert George Wells, in cui l'autore descrive l'invasione del pianeta ad opera di marziani. Wells è preoccupato da un possibile scontro con l'Impero tedesco e nel 1908 pubblica The War in the Air in cui la Germania attacca gli Stati Uniti per il dominio del mondo. Questo romanzo comprende la visione apocalittica che ossessiona i lettori di fine Ottocento e anticipa gli orrori dei bombardamenti aerei. Nel 1910, anno dell'ascesa al trono di re Giorgio V, viene pubblicato The Great Illusion di Norman Angell. La grande illusione a cui allude l'autore è la convinzione, molto diffusa in Europa all'inizio del Ventesimo secolo, di una imminente e catastrofica guerra fra le potenze europee. Un'altra opera sulla minaccia tedesca è When William Came di Saki, pseudonimo di Hector Hugh Munro, pubblicata del 1913. Saki parla di un'invasione del Regno Unito da parte della Germania e della conseguente annessione delle isole britanniche all'Impero germanico. Lopera presagio della Prima guerra mondiale è The World Set Free: A 
Story of Mankind, pubblicato ancora da Wells proprio nei primi mesi del 1914. L'autore parla di una guerra, l'ultima del genere umano, combattuta nel 1950 da Francia e Regno Unito contro la Germania e altre potenze dell'Europa centrale.

Il successo di questi romanzi dimostra una radicata paura di una possibile dominazione tedesca e suggerisce anche che lo scoppio della Prima guerra mondiale sia stato in qualche modo immaginato da molti anni. I nemici ipotetici sono solitamente Francia, Russia, Stati Uniti d'America e, appunto, Germania. In particolare quest'ultima viene vista come la principale e probabile nemica e ciò riflette il tentativo tedesco di insidiare il Regno Unito nel ruolo di potenza mondiale. Proprio il timore di un'invasione è forse il motivo per cui la violenta aggressione tedesca del Belgio nell'agosto 1914 scuote i cittadini britannici (fig. 1).

Fig. 1. Vignetta allegorica dell'invasione tedesca ai danni del Belgio, opera dell'illustratore Frederick Henry Townsend e pubblicata nell'agosto 1914 su Punch Magazine

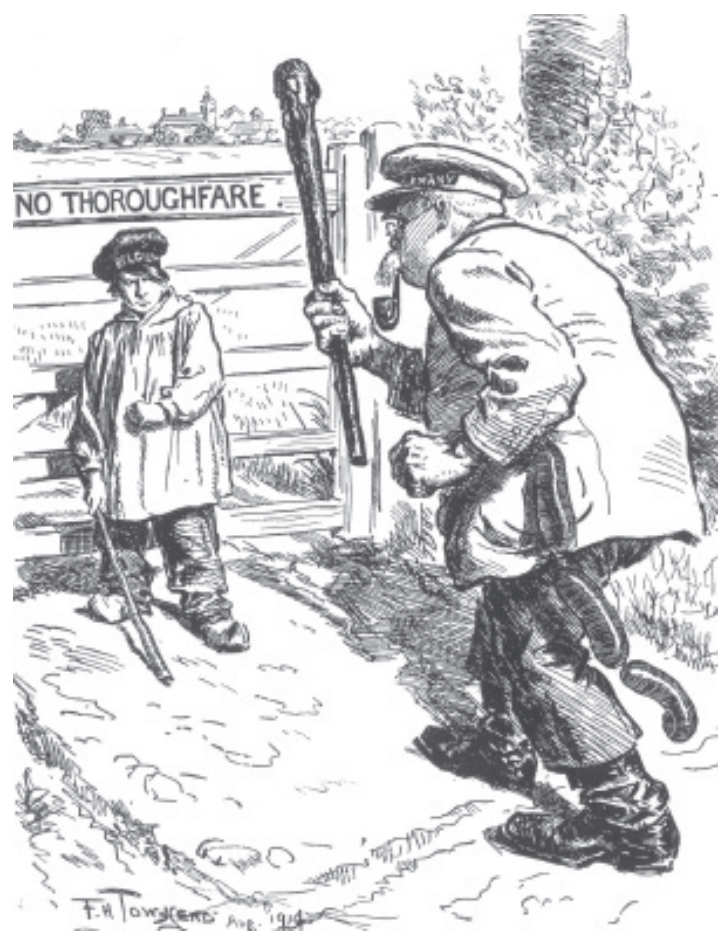




\section{Nazionalismo e patriottismo nella letteratura prebellica}

Nel Regno Unito, al momento dello scoppio della guerra, è già presente un linguaggio poetico appropriato ai sentimenti prevalenti e potenzialmente utile a raccontare il conflitto. Nelle sale da ballo diventano popolari vecchie canzoni patriottiche come The Dogs of War di George William Hunt (Shea e Whitla, 2015, 154), scritta nel 1877 in occasione della decisione del governo britannico di supportare la Turchia contro l'invasione russa. L'autore cerca una facile identificazione fra il pubblico e lo Stato britannico in modo da risvegliare sentimenti patriottici. Il primo pronome personale plurale è ripetuto spesso, infatti, ed è legato alla potenza e alla ricchezza del paese. È interessante notare come i soldati vengano posti sullo stesso livello delle navi e del denaro, quasi come fossero oggetti inanimati.

\section{$[\ldots]$}

We don't want to fight, but by Jingo ${ }^{[1]}$ if we do,

We've got the ships, we've got the men, and got the money too,

We've fought the Bear before, and while we're Britons true,

The Russians shall not have Constantinople.

$[\ldots]$

Molta letteratura vittoriana e diversi lavori dei primi anni del Ventesimo secolo presentano grande interesse per la violenza. Viene senz'altro in mente Rudyard Kipling, ma non è l'unico esempio. Nel 1893 William Ernest Henley pubblica The Song of the Sword (Chandler e Nauright, 2013, 145), dedicata proprio a Kipling. Gli ultimi due versi ricordano le parole di Gesù: "Non crediate che io sia venuto a portare la pace sulla terra. Non sono venuto a portare la pace, ma la spada" (Vangelo di Matteo 10,34):

$[\ldots]$

Clear singing, clean slicing;

Sweet spoken, soft finishing;

[1] Il termine "jingo" proviene dalla parola basca "Jainko" che significa Dio, così l'espressione "by Jingo!" è sinonimo di "By God!". Si pensa che questa espressione venga usata per la prima volta quando re Edoardo I (1239-1307) ingaggia i mercenari baschi per combattere in Galles. Fino alla guerra russo-turca del 1877-1878 la parola "jingo" è usata per descrivere una persona rozza e stolta ma dalla canzone di Hunt in avanti viene associata all'immagine di una persona estremamente nazionalista, patriottica e, di solito, guerrafondaia. 
Making death beautiful,

Life but a coin

To be staked in the pastime

Whose playing is more

Than the transfer of being;

Arch-anarch, chief builder,

Prince and evangelist,

I am the Will of God:

I am the Sword.

$[\ldots]$

Anche Alfred Edward Housman, in A Shropshire Lad (1896), esalta violenza, onore, coraggio e sacrificio. L'associazione fra giovinezza e morte è un binomio indissolubile e nel terzo canto (Housman, 1985, 42) l'autore celebra il coraggio in battaglia:

$[\ldots]$

Come you home a hero,

Or come not home at all,

The lads you leave will mind you

Till Ludlow tower shall fall.

$[\ldots]$

Un altro importante esempio di violenza letteraria è Altaforte (Lehman, 2006, 296-297), una delle prime poesie di Ezra Pound, in cui l'autore commemora le bellicose inclinazioni di un gentiluomo provenzale. In questo componimento emerge il tema della necessaria sovrapposizione dei ruoli del poeta e del combattente politico. Tramite una serie di scene medioevali di battaglia, Pound esprime, pur situando la scena in un passato storico, la propria nostalgia per un'epoca in cui i poeti non hanno abdicato all'azione e osano combattere la stagnante ipocrisia.

$[\ldots]$

And I love to see the sun rise blood-crimson.

And I watch his spears through the dark clash

And it fills all my heart with rejoicing

[...]

The man who fears war and squats opposing

My words for stour, hath no blood of crimson

But is fit only to rot in womanish peace 


\section{[...]}

And let the music of the swords make them crimson!

Hell grant soon we hear again the swords clash!

Hell blot black for always the thought 'Peace'.

Tali esempi letterari sono il frutto di un Regno Unito da molti decenni in pace all'interno dei propri confini, e di una concezione della stessa come qualcosa di insopportabilmente noioso. Anche per questo motivo la dichiarazione di guerra viene accolta con generale eccitazione e fervore patriottico. Nonostante la coscrizione non sia ancora obbligatoria, gli appelli del governo al reclutamento riscuotono enorme successo: nell'agosto del 1914 in migliaia rispondono alla chiamata alle armi, applauditi dalla popolazione civile (fig. 2).

Fig. 2. Fila presso l'ufficio di reclutamento Whitehall a Londra nell'agosto 1914 (C) IWM (Q 42033)

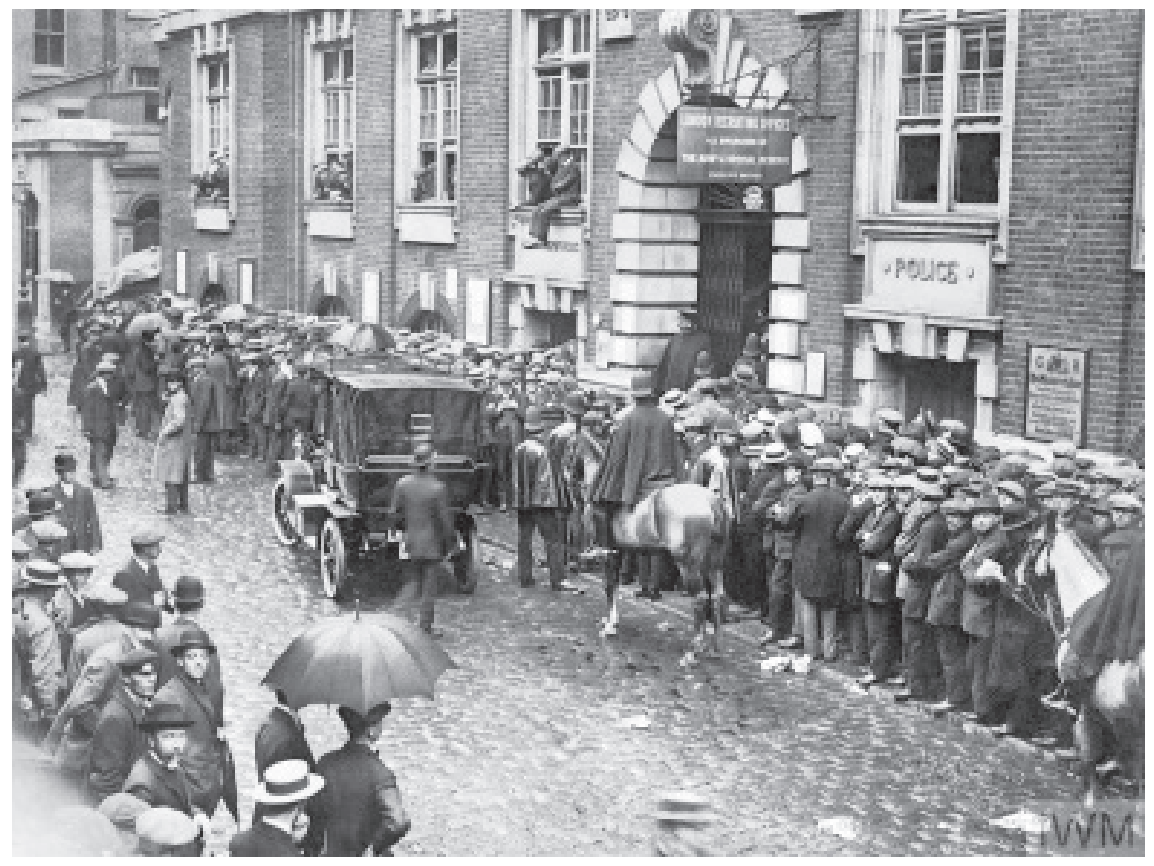




\section{La guerra è un gioco}

In tempi recenti il paese è stato coinvolto in conflitti combattuti da professionisti su fronti lontani dall'Europa. Sono diffusi i ricordi del conflitto boero che, uniti a generici sentimenti nazionalistici che fanno della guerra un'avventura romantica, attraggono l'immaginazione di molti britannici. Giornali e romanzi inoltre hanno sempre dipinto le battaglie come qualcosa di affascinante ed esotico: a questa generazione la guerra appare come un modo per ritardare l'impatto con la vita adulta, una fuga dai problemi (fig. 3).

Fig. 3. Cartolina dell'illustratore Douglas Tempest, pubblicata nel 1916 dall'agenzia Bamforth \& Co, con le parole di una famosa canzone scritta dai fratelli Powell nel 1915

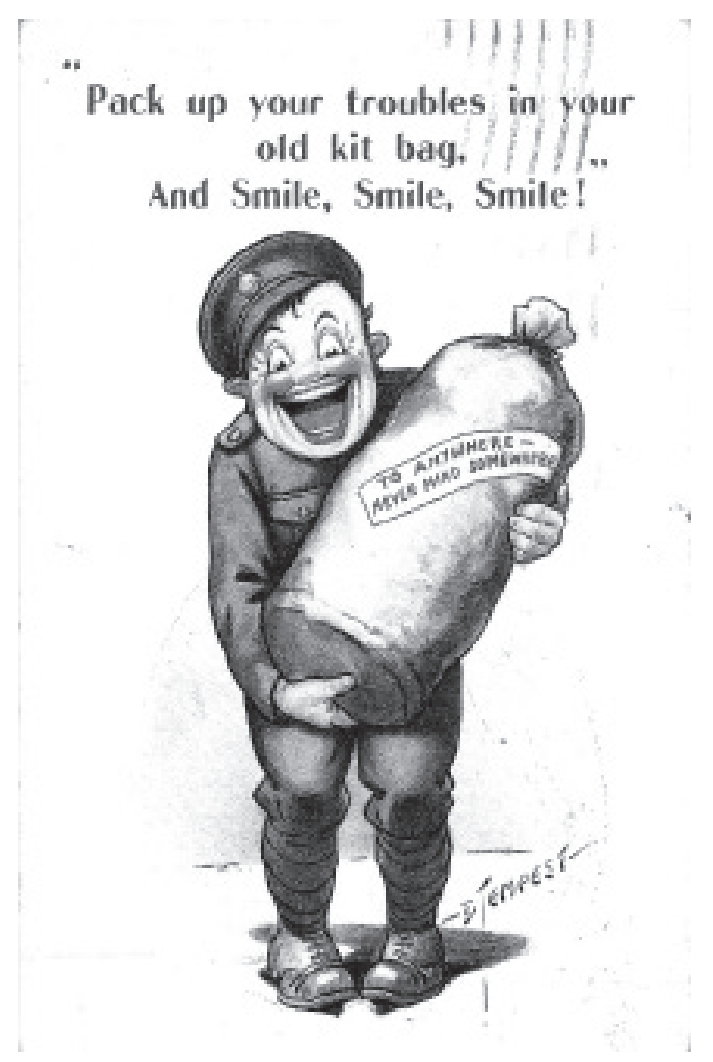


L'estate del 1914 è diventata nell'immaginario moderno il simbolo dell'innocenza perduta di una lost generation, la cui ingenuità si manifesta, per esempio, nella visione della guerra come una gara sportiva. L'equazione guerra-sport è proposta da Sir Henry Newbolt in Vitaï Lampada già nel 1892. Qui uno studente viene incoraggiato dal capitano della squadra di cricket durante una partita; una volta in guerra, il ragazzo si ricorda le parole del suo compagno di squadra e sprona allo stesso modo i commilitoni al momento di andare in battaglia:

There's a breathless hush in the Close tonight -

Ten to make and the match to win:

A bumping pitch and a blinding light,

An hour to play and the last man in.

And it's not for the sake of a ribboned coat,

Or the selfish hope of a season's fame,

But his Captain's hand on his shoulder smote:

"Play up! play up! and play the game!"[2]

$[\ldots]$

Per molti giovani di campagna arruolarsi significa anche avere una paga giornaliera, cibo e alloggio. Nei giovani delle classi più agiate, cresciuti nelle public schools, si afferma invece la convinzione che la guerra sia solo la continuazione di un gioco a squadre. Le public schools insegnano senso del dovere, patriottismo, eroismo e cameratismo, che trovano una concreta espressione nei giochi sportivi organizzati a scuola. I valori sportivi del cricket, simbolo di tutto ciò che rappresenta essere britannici, si possono quindi applicare anche in ambito bellico a tal punto che, per il poeta Theodore Percival Cameron Wilson, il paradiso degli eroi morti in battaglia ha l'aspetto di un campo da gioco. In Sportsmen in Paradise (Martines, 2016, 137-138), Wilson scrive:

They left the fury of the fight,

And they were very tired.

The gates of Heaven were open quite,

Unguarded and unwired.

There was no sound of any gun,

The land was still and green;

[2] Poesia disponibile anche online su: https://www.poemhunter.com/poem/vita-lampada/ (consultato il 23/06/2020) 
Wide hills lay silent in the sun,

Blue valleys slept between.

They saw far-off a little wood

Stand up against the sky.

Knee-deep in grass a great tree stood;

Some lazy cows went by...

There were some rooks sailed overhead,

And once a church-bell pealed.

"God! but it's England", someone said,

"And there's a cricket-field!"

Un'altra dimostrazione di questo spirito sportivo consiste nell'usanza di calciare un pallone verso le linee nemiche al momento dell'attacco. Il primo a farlo è il I battaglione del London Regiment nel 1915 e l'episodio più famoso è quello che ha come protagonista il capitano Wilfred Percy Nevill. Nella sua ultima licenza a Londra, Nevill acquista quattro palloni da calcio, uno per ciascun plotone. Una volta tornato al fronte, durante la prima giornata della battaglia della Somme, offre un premio al plotone che, al momento dell'attacco, riuscirà a buttare il pallone nelle linee tedesche. Questa piccola gara serve a persuadere i suoi uomini che l'attacco avrà successo. Il capitano Nevill muore in azione quasi subito. Uno dei quattro palloni (fig. 4) è ora conservato al Queen's Royal Surrey Regimental Museum.

Fig. 4. Uno dei palloni da calcio usati in battaglia dal reggimento del capitano Nevill

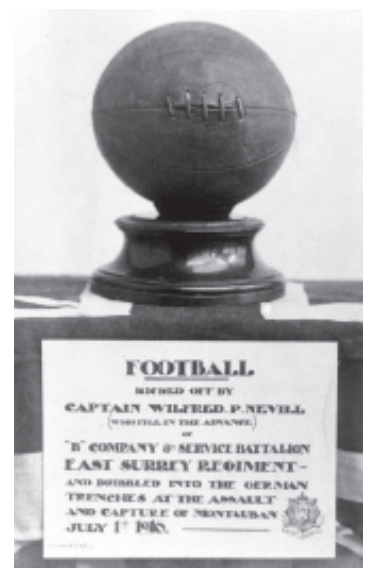




\section{Il mito di Rupert Brooke}

Rupert Brooke, pur non avendo mai combattuto, è spesso ricordato come il "poeta di guerra" britannico che ha ispirato il patriottismo nei primi mesi del conflitto, trasformandosi nel mito di un guerriero giovane e bello caduto in battaglia. Si arruola immediatamente e nel settembre 1914 salpa con la sua divisione verso Anversa, città che è sotto assedio tedesco. Dalle sue prime lettere emerge un sentimento di terrore ed euforia, così come scrive all'amico Edward Marsh (Brooke, 1987, 140):

\section{[...] Every mile the noise got louder, immense explosions and detonations [...] five or six thousand British troops, a lot of Belgians, guns going through, transport-waggons, motor cyclists, staff officers. [...] An extraordinary and thrilling confusion. As it grew dark the thunder increased, and the sky was lit by extraordinary glares. We were all given entrenching tools. Everybody looked worried. [...]}

In un'altra lettera del 1914 lamenta il fatto che più della metà della nazione sia indifferente alla guerra: "People don't want to die. Which is odd. I've been praying for a German raid" (Brooke, 1968, 36). Brooke ritiene di aver assistito ad un crimine orribile e da questo momento il conflitto diventa una guerra per la liberazione del Belgio. In una lettera, scritta il giorno di Natale del 1914, Brooke descrive un episodio della sua esperienza nelle Fiandre (Brooke, 1968, 32):

[...] Antwerp that night was like several different kinds of hell - the broken houses and dead horses lit up by an infernal glare. The refugees were the worst sight. The German policy of frightfulness had succeeded so well, that out of that city of half a million, when it was decided to surrender Antwerp. I'll never forget that white-faced, endless procession in the night [...] the old men crying, and the women with hard drawn faces. [...]

Il sonetto The Soldier (Giddings, 1988, 25), scritto all'inizio della guerra, riassume bene il nazionalismo e l'esaltazione presenti nel paese. Lautore decanta una morte eroica in terra straniera, che purifica e rende immortali. La concentrazione su un'Inghilterra rurale è usata qui come 
punto di partenza per una riflessione sulla possibilità della propria morte. Il corpo e la terra sono misticamente identificati:

If I should die, think only this of me:

That there's some corner of a foreign field

That is for ever England. There shall be

In that rich earth a richer dust concealed;

A dust whom England bore, shaped, made aware,

Gave, once, her flowers to love, her ways to roam,

A body of England's, breathing English air,

Washed by the rivers, blest by sun of home.

And think, this heart, all evil shed away,

A pulse in the eternal mind, no less

Gives somewhere back the thoughts by England given;

Her sights and sounds; dreams happy as her day;

And laughter, learnt of friends; and gentleness,

In hearts at peace, under an English heaven.

Brooke riceve la notizia del suo trasferimento allo stretto dei Dardanelli e in una lettera di marzo (Brooke, 1968, 45) emerge il suo ottimismo e l'impazienza di combattere. Sembra felice fino alla sera del 20 aprile 1915, quando accusa dei forti dolori alla schiena e al collo, oltre ad una febbre molto alta. I medici parlano di setticemia, viene trasferito in un ospedale francese e cade in coma. Muore il 23 aprile 1915 senza conoscere le orribili atrocità della guerra in trincea.

\section{Wilfred Owen e l'incontro con Siegfried Sassoon}

La situazione sul Fronte occidentale già all'inizio del 1915 appare confusa, la guerra è giunta ad un punto morto e la carenza di soldati rappresenta un serio problema ${ }^{[3]}$. Rispetto all'iniziale e diffuso entusiasmo che segue l'entrata nel conflitto, possiamo notare un netto cambiamento nella poetica dopo la battaglia della Somme del luglio 1916, vero spartiacque nella concezione della guerra. Nella produzione anteriore a questa battaglia si evidenziano l'idea di combattere per una giusta causa

[3] Per tale ragione il governo britannico nel maggio 1916 approva il Military Service Act, che estende la coscrizione obbligatoria per tutti gli uomini dai 18 ai 41 anni. 
e gli aspetti eroici del sacrificio; nei testi poetici scritti dopo il 1916, invece, prevale il profondo senso di delusione e disillusione, dovuto all'enorme spreco di vite umane. Wilfred Owen e Siegfried Sassoon rappresentano questa seconda fase.

Owen, come molti suoi contemporanei, pensa si debba combattere quest'ultima guerra: è infatti opinione diffusa che l'intervento degli Alleati sconfiggerà la minaccia militare tedesca per ristabilire definitivamente la pace in Europa. Qualcosa nel giovane Wilfred cambia quando è costretto a restare per alcuni giorni sotto il fuoco nemico, avendo sotto gli occhi il corpo mutilato di un compagno ufficiale. Da questo momento, datato aprile 1917, le emozioni dominanti sono l'orrore, lo sdegno e la pietà: orrore per ciò che vede al fronte, sdegno per l'incapacità del mondo civile di comprendere che cosa sta accadendo e pietà per i poveri ed inermi ragazzi in guerra, anche per i soldati tedeschi.

In seguito a questo traumatico evento, i medici gli diagnosticano la nevrastenia, un disturbo funzionale del sistema nervoso determinato da irritabilità e incubi ricorrenti, e a giugno lo trasferiscono nell'ospedale psichiatrico di Craiglockhart. Qui conosce Sassoon, di cui è un grande ammiratore, e scrive alcuni dei suoi versi più noti. Fa sua la critica agli ufficiali ed al fronte interno, tipica di Sassoon, dal quale riprende anche il linguaggio semplice, come si può notare in The Letter (Owen, 1965, 60), scritta nell'agosto 1917. Si narra di un soldato intento a scrivere una lettera alla moglie, la scena è però interrotta da frasi rivolte all'amico di fianco a lui. In queste frasi, scritte fra parentesi, Owen fa ampio uso di un linguaggio parlato:

With B.E.F. June 10. Dear Wife,

(O blast this pencil. 'Ere, Bill, lend's a knife.)

I'm in the pink at present, dear.

I think the war will end this year.

We don't see much of them square-'eaded 'Uns.

We're out of harm's way, not bad fed.

I'm longing for a taste of your old buns.

(Say, Jimmie, spare's a bite of bread.)

there don't seem much to say just now.

(Yer what? Then don't, yer ruddy cow!

And give us back me cigarette!)

$[\ldots]$ 
Il sentimento che prevale nella poesia Strange Meeting (Kermode e Hollander, 1973, 2050), scritta nell'agosto 1918, è la consapevolezza che il nemico altro non è che un giovane simile a lui. L'io narrante si chiede se sotto le spoglie del soldato appena trucidato si nasconda in realtà un coetaneo con gli stessi sogni infranti, se non addirittura un suo alter ego. Il dialogo fra i due chiarisce questa similitudine: tutte le speranze dell'uno appartengono anche all'altro, ma la guerra le ha cancellate. La disillusione e gli anni sprecati di cui parla il nemico possono riferirsi allo stesso Owen, come testimoniano i versi centrali della poesia.

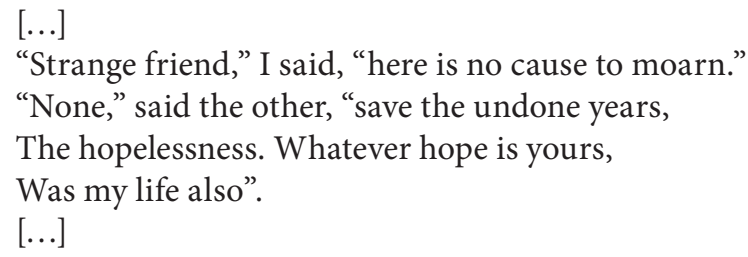

Per Owen il compito principale del poeta non è tanto raccontare la realtà, quanto avvisare e ammonire le giovani generazioni sulle conseguenze della guerra. Nella prefazione alle sue poesie (Freer e Andrew, 1970, 120), composta probabilmente nell'estate del 1918, Owen chiarisce così lo scopo della sua raccolta:

This book is not about heroes. English poetry is not yet fit to speak of them. Nor is about deeds, or lands, nor anything about glory, honour, might, majesty, dominion, or power, except War. Above all I am not concerned with Poetry. My subject is War, and the pity of War. The Poetry is in the pity. Yet these elegies are to this generation in no sense consolatory. They may be to the next. All a poet can do today is warn. That is why the true Poets must be truthful.

Owen, avendo visto le sofferenze dei soldati, vuole essere loro vicino ed è deciso a dedicare le sue energie alla poesia, grazie anche all'incoraggiamento di Sassoon, che dimostra di apprezzare i suoi lavori. Nel settembre 1918 è di nuovo in prima linea e il 4 novembre viene ferito mortalmente. Il mattino dell'11 novembre, quando le campane del suo paese natale suonano per festeggiare l'armistizio, arriva a casa dei suoi genitori il telegramma. Wilfred muore a soli venticinque anni. 


\section{Siegfried Sassoon e la sua poetica}

Il sentimento di esaltazione iniziale per lo scoppio della guerra è condiviso anche da Siegfried Sassoon, il quale saluta l'inizio del conflitto con accenti simili a quelli di Brooke, a volte addirittura imitandolo, come lui stesso ammetterà nella sua autobiografia (Sassoon, 1947, 17). Si vedano soprattutto la seconda e la terza quartina di Absolution (Johnston, 2015, 84), scritta fra l'aprile e il settembre 1914:

\section{$[\ldots]$}

Horror of wounds and anger at the foe,

And loss of things desired; all these must pass.

We are the happy legion, for we know

Time's but a golden wind that shakes the grass.

There was an hour when we were loth to part

From life we longed to share no less than others.

Now, having claimed this heritage of heart,

What need we more, my comrades and my brothers?

che riecheggia il finale del sonetto The Dead di Brooke (Brooke, 2020, 110):

\section{$[\ldots]$}

Blow, bugles, blow! They brought us, for our dearth,

Holiness, lacked so long, and Love, and Pain,

Honour has come back, as a king, to earth,

And paid his subjects with a royal wage;

And Nobleness walks in our ways again;

And we have come into our heritage.

Nel 2004 la studiosa statunitense Jean Moorcroft Wilson ha ritrovato una poesia inedita di Sassoon, scritta quasi certamente prima di essere mandato al fronte francese. La lirica, databile fra l'aprile e il settembre 1915, è stata intitolata Because We Are Going e sembra evidente ancora l'influenza di Brooke. Sassoon sottolinea le rinunce dei soldati, che abbandonano le certezze, gli amori e l'allegra spensieratezza. Dietro ai loro volti sorridenti si nascondono paura e terrore, vinte dalla consapevolezza di 
un dovere più grande, quello di combattere per la patria. La guerra appare come una sorta di battesimo che redime e purifica dai peccati.

Because we are going from our wonted places

To be task-ridden by one shattering Aim, And terror hides in all our laughing faces That had no will to die, no thirst for fame, Hear our last word in hell we seek for Heaven; The agony of wounds shall make us clean; And the failure of our sloth shall be forgiven When Silence holds the songs that might have been, And what we served remains superb, unshaken, England our June of blossom that shines above Disastrous War; for whom we have forsaken Ways that were rich and gleeful and filled with love. Thus are we heroes; since we might not choose To live where Honour gave us life to lose. ${ }^{[4]}$

Nel componimento To Victory (gennaio 1916), l'autore afferma di essere alla ricerca di gloria e fama: "I am not sad; only I long for lustre" (Sassoon, 2012, 5). Non passa molto tempo prima che emergano invece sentimenti come paura, delusione e cinismo. Il cambiamento nella sua poetica si nota chiaramente in The Poet as Hero (Kendall, 2013, 94-95), pubblicata il 2 dicembre del 1916 su The Cambridge Magazine. Sassoon si batte il petto per il suo stupido entusiasmo iniziale, che lo ha portato a vedere la guerra come una crociata alla ricerca del sacro Graal, e spiega come la sofferenza abbia trasformato la sua gioia in un triste pianto. Lultimo verso è un chiaro riferimento alla propria poesia Absolution.

You've heard me, scornful harsh, and discontented, Mocking and loathing War: you've asked me why

Of my old, silly sweetness I've repented -

My ecstasies changed to an ugly cry.

You are aware that once I sought the Grail,

Riding in armour bright, serene and strong;

And it was told that through my infant wail

There rose immortal semblances of song.

But now I've said good-bye to Galahad,

[4] Poesia disponibile anche online su: https://www.theguardian.com/uk/2004/nov/13/books.booksnews (consultato il 23/06/2020). 
And am no more the knight of dreams and show:

For lust and senseless hatred make me glad, And my killed friends are with me where I go.

Wound for red and Wound I burn to smile their wrongs;

And there is absolution in my songs.

Nel 1917, dopo l'ecatombe della battaglia della Somme, Sassoon pubblica il famoso A Soldier's Declaration, presentato in Parlamento da Bertrand Russell. Si scaglia contro chi ha volutamente prolungato la guerra e non intende più essere complice di uno stato maggiore che non si adoperi per fermare il conflitto. Non contesta il modo in cui è stato condotto il conflitto, ma le scelte politiche e le menzogne che vi si celano.

I am making this statement as an act of wilful defiance of military authority, because I believe that the War is being deliberately prolonged by those who have the power to end it. I am a soldier, convinced that I am acting on behalf of soldiers. I believe that the purposes for which I and my fellow soldiers entered upon this War should have been so clearly stated as to have made it impossible to change them, and that, had this been done, the objects which actuated us would now be attainable by negotiation.

I have seen and endured the sufferings of the troops, and I can no longer be a party to prolong these sufferings for ends which I believe to be evil end unjust.

I am not protesting against the conduct of the War, but against the political errors and insincerities for which the fighting men are being sacrificed. ${ }^{[5]}$

L'autore diffonde le proprie idee pacifiste e rischia, pertanto, la corte marziale. L'amico Robert Graves, pur condividendo le ragioni di Sassoon, è convinto che il suo gesto gli recherebbe solo danni senza conseguire alcun risultato. Grazie a conoscenze influenti, Graves riesce a farlo dichiarare mentalmente instabile dal consiglio di sanità. Siegfried viene così trasferito nell'ospedale psichiatrico di Craiglockhart e, durante la convalescenza, scrive Great Men (agosto 1917), in cui non rinuncia ad esprimere astio verso coloro che potrebbero fermare la guerra, siano essi generali, principi o politici. Questi “grandi uomini” sono responsabili di

[5] Testo dispobile anche online su: https://www.theguardian.com/commentisfree/2009/nov/04/siegfriedsassoon-afghanistan (consultato il 23/06/2020). 
crimini mostruosi, ignorando le conseguenze della guerra e il suo altissimo prezzo di vite umane:

The great ones on earth

Approve, with smiles and bland salutes, the rage

And monstrous tyranny they have brought to birth.

The great ones of the earth

Are much concerned about the wars they wage,

And quite aware of what those wars are worth.

You Marshals, gilt and red,

You Ministers and Princes, and Great Men,

Why can't you keep your mouthings for the dead?

Go round the simple cemeteries; and then

Talk of our noble sacrifice and losses

To the wooden crosses. ${ }^{[6]}$

Una volta ripresosi ed essendosi convinto di aver abbandonato i suoi uomini al fronte, Sassoon ritorna in azione. Il motivo dominante adesso è la compassione verso i soldati. Nel marzo 1919, scrive Aftermath (Sassoon, 1983, 132-133) una delle sue ultime liriche sulla Prima guerra mondiale. L'io narrante ricorda con chiarezza e precisione la vera faccia della guerra: le notti di guardia, il tanfo dei cadaveri in decomposizione, $\mathrm{i}$ momenti prima dell'attacco, l'incessante pioggia, la rabbia e la compassione nel fissare i propri uomini condannati a morte. È un appello ai soldati per non dimenticare gli orrori della guerra nella speranza, vana, che tutto ciò non si ripeta.

Have you forgotten yet?...

For the world's events have rumbled on since those gagged days, Like traffic checked while at the crossing of city-ways:

And the haunted gap in your mind has filled with thoughts that flow

Like clouds in the lit heaven of life; and you're a man reprieved to go,

Taking your peaceful share of Time, with joy to spare.

But the past is just the same - and War's a bloody game...

Have you forgotten yet?...

[6] Testo dispobile anche online su: http://jamesmanlow.com/siegried-sassoon-first-world-war-poems (consultato il 23/06/2020). 
Look down, and swear by the slain of the War that you'll never forget.

Do you remember the dark months you held the sector at Mametz -

The nights you watched and wired and dug and piled sandbags on parapets?

Do you remember the rats; and the stench

Of corpses rotting in front of the front-line trench -

And dawn coming, dirty-white, and chill with a hopeless rain?

Do you ever stop and ask, 'Is it all going to happen again?'

Do you remember that hour of din before the attack -

And the anger, the blind compassion that seized and shook you

then

As you peered at the doomed and haggard faces of your men?

Do you remember the stretcher-cases lurching back

With dying eyes and lolling heads - those ashen-grey

Masks of the lads who once were keen and kind and gay?

Have you forgotten yet?...

Look up, and swear by the green of the spring that you'll never forget.

\section{Conclusioni}

La poesia della Grande Guerra sembra, sotto molti punti di vista, una "parentesi" nel panorama della letteratura inglese del Ventesimo secolo. Variegata ed eterogenea sul piano stilistico e tematico, la poesia dei war poets è il prodotto di un determinato periodo storico e culturale, caratterizzato dal patriottismo e dall'imperialismo nella tarda età vittoriana e nella prima età edoardiana.

Già la figura del poeta-soldato connota diversamente il prodotto poetico rispetto alla tradizione della letteratura sulla guerra ${ }^{[7]}$, la quale, essendo spesso priva di un confronto con le vicende belliche ${ }^{[8]}$, ha generalmente sortito esiti retorici e mitizzanti. Sono proprio, invece, l'asprezza dell'urto e il tributo pagato in prima persona a dissolvere presto

[7] Si vedano a tal proposito gli esempi analizzati nel secondo capitolo.

[8] Fanno eccezione alcune opere come il Don Juan di Byron. 
nei versi dei war poets ogni cortina illusoria e nobilitante (Guerra, 1980, 8-9). In tanti autori si può infatti osservare un vistoso cambiamento per quanto riguarda la concezione della guerra, con conseguenze anche sui temi trattati e sulla poetica. Lardore e il patriottismo, che caratterizzano i primi mesi di conflitto, lasciano presto spazio alla disillusione e all'orrore. E c'è chi, come Owen, lancia il proprio appello attraverso la poesia per raccontare, in prima persona, l'assurdità disumanizzante della guerra e dare voce a chi voce non ha, i soldati.

Al fine di capire meglio i poeti britannici della Grande Guerra e le loro opere, occorre fare una banale ma utile precisazione. Se per war poet si intende chi scrive in guerra e sulla guerra allora Rupert Brooke che muore nell'aprile 1915, ancor prima di combattere - non può essere considerato tale. Tuttavia, se "poeta di guerra" sta ad indicare la più larga categoria di coloro che vivono la crisi degli ideali vittoriani, portata al suo culmine dalla guerra del 1914-18, anche Brooke può rientrare nell'ambito di tale definizione.

La maggior parte di questi autori ha frequentato Oxford o Cambridge e ha un'elevata posizione sociale. Il fatto che molti poeti siano ufficiali - ma non alti ufficiali - permette loro di essere in contatto, a livello socio-culturale, con i ranghi elevati dell'esercito e, fisicamente, con i soldati semplici. I poeti appartengono spesso all'esercito anche perché le altre due forze armate, marina ed aviazione, sono meno presenti nel conflitto. Non si deve inoltre dimenticare che la prospettiva dei war poets è quella di ufficiali, spesso giovani. Si capisce allora come la poesia di guerra si focalizzi su un'esperienza diretta ma personale, quindi parziale: questa è una considerazione tanto ovvia quanto importante. Tutti i war poets hanno in comune la giovinezza ${ }^{[9]}$ e l'aver combattuto in guerra, a parte Brooke; alcuni sono morti, altri sono tornati mutilati o hanno passato lunghi anni in ospedali psichiatrici.

Uno degli elementi più interessanti della Grande Guerra è anche l'elevato numero di poesie che ha saputo ispirare, fornendo un quadro dei soldati britannici molto preciso: hanno un retroterra culturale mediamente superiore a quello dei militari di altre nazionalità. Nel 1914 non soltanto alcuni soldati sono dei letterati, ma dei letterati in piena regola, perché

[9] A parte, per esempio, Edward Thomas, che muore nel 1917 all'età di 39 anni. 
la Grande Guerra si verifica nel particolare momento storico in cui nel Regno Unito si ha la straordinaria coincidenza di due forze "liberal". Da un lato è ancora forte la fiducia nei poteri educativi della letteratura inglese e classica; dall'altro la richiesta di istruzione popolare è al culmine, e tale istruzione è concepita in termini umanistici. L'intersezione di queste due forze crea un'atmosfera di generale interesse per la letteratura (Fussell, 1975, 199).

Alle poesie si aggiungono le lettere, una miniera di documenti che resta nella sua maggior parte inesplorata perché molto vasta. L'esperienza di guerra viene vissuta quindi in termini letterari non soltanto dai poeti ma, come testimonia la corrispondenza dei soldati coi familiari, anche da una vastissima fascia di combattenti, culturalmente e socialmente eterogenea. 


\section{Bibliografia}

Bergonzi, Bernard (1965). Heroes' Twilight - A Study of the Literature of the Great War, London: Constable \& Co.

Brooke, Rupert (1968). The Letters of Rupert Brooke, London: Faber and Faber.

Brooke, Rupert (1987), The Collected Poems, London: Sidgwick and Jackson.

Brooke, Rupert (2020), The Poems of Rupert Brooke, Mineola: Dover Publications.

Chandler, Timothy J.L., Nauright, John (2013). Making Men: Rugby and Masculine Identity. London: Routledge.

Freer, Allen, Andrew, John (1970), Cambridge Book of English Verse 199039, Cambridge: Cambridge Univerity Press.

Fussell, Paul (1975). La grande guerra e la memoria moderna, Oxford: Oxford University Press.

Giddings, Robert (1988). The War Poets, London: Bloomsbury Publishing. Guerra, Lia (1980). La polvere e il segno. Poeti inglesi della prima guerra mondiale, Milano: Cisalpino - La Goliardica.

Housman, Alfred Edward (1985). A Shropshire Lad, London: Harrap \& Co. Johnston, John H. (2015). English Poetry of the First World War, Princeton: Princeton Unversity Press.

Kendall, Tim (2013). Poetry of the First World War: An Anthology. Oxford: Oxford University Press.

Kermode, Frank, Hollander, John (1973). The Oxford Anthology of English Literature - Volume II, Oxford: Oxford University Press.

Lehman, David (2006). The Oxford Book of American Poetry, New York: Oxford University Press.

Martines, Enrico (2016). Play the game!: Come gli inglesi inventarono lo sport moderno, Padova: Libreria Universitaria Edizioni. 
Owen, Wilfred (1965). The Collected Poems of Wilfred Owen, New York: New Directions Publishing.

Sassoon, Siegfried (1947). Siegfried's Journey 1916-1920, London: Faber and Faber.

Sassoon, Siegfried (1983). The War Poems, London: Faber and Faber.

Sassoon, Siegfrid (2012). War Poems of Siegfried Sassoon. Mineola: Dover Publications.

Shea, Victor, Whitla, William (2015). Victorian Literature: An Anthology. Hoboken: John Wiley \& Sons.

Trevelyan, George Macaulay (1977). Storia dell'Inghilterra, Milano: Garzanti. 


\section{Summary}

The image of a United Kingdom as an Eden unaware of the tragedy that is about to tear it apart is widespread but rather false. The apparent serenity hides a latent violence and a huge inner problems and the war, therefore, only accelerates a process already underway.

Of all the English literature of the twentieth century, war poetry seems, from many points of view, a "parenthesis" within the literary panorama. War poetry is the product of a specific historical, social and cultural period that came to form in the First World War. Rupert Brooke, Wilfred Owen and Siegfried Sassoon are probably some of the best poets of the Great War. Many war poets are young commissioned officers with a good education and high social position. The fact that many poets are commissioned officers - but not high officers - allows them to have a certain overview of the war and to be in contact on a socio-cultural level with the high ranks of the army and, physically, with privates. In this way they manage to have a wider vision of reality in the trenches.

Keywords: war poets, Grande Guerra, Rupert Brooke, Wilfred Owen, Siegfrid Sassoon 
